\title{
1. A importância da pesquisa na cirurgia plástica brasileira ${ }^{1}$
}

\author{
The significance of research in the Brazilian plastic surgery
}

\section{Lydia Masako Ferreira ${ }^{2}$, Fabio Xerfan Nahas ${ }^{3}$}

1. Programa de Pós-Graduação em Cirurgia Plástica da Universidade Federal de São Paulo - Escola Paulista de Medicina (UNIFESP-EPM). Disciplina de Cirurgia Plástica da UNIFESP-EPM.

2. Professora Titular da Disciplina de Cirurgia Plástica da UNIFESP-EPM. Coordenadora do Programa de Pós-Graduação em Cirurgia Plástica da UNIFESP-EPM.

3. Professor Adjunto Visitante da Disciplina de Cirurgia Plástica da UNIFESP-EPM. Professor Orientador do Programa de Pós-Graduação em Cirurgia Plástica da UNIFESP-EPM

A idéia de desenvolver um suplemento sobre como escrever um trabalho científico, voltado à Cirurgia Plástica, originou-se da constatação de que muitos cirurgiões plásticos não ligados à universidade, embora tivessem idéias criativas e inovadoras, apresentavam uma certa dificuldade na elaboração e desenvolvimento de um trabalho científico. Este fato, por vezes pode inviabilizar a divulgação de técnicas importantes. Desta forma, este suplemento foi elaborado objetivando a orientação de qualquer pesquisador da área médica que deseje desenvolver um estudo que envolva a Cirurgia Plástica.

Neste suplemento procurou-se inserir artigos que se complementam de forma a tornar possível a compreensão de todas as fases envolvidas na elaboração do trabalho científico até sua publicação.

A eficácia da transmissão de como se elabora um trabalho científico é fundamental na realização de teses. Este é um dos pontos de garrote da evolução de um aluno na pós-graduação sensu stricto. A Pós-Graduação em Cirurgia Plástica da UNIFESP - EPM, tem dedicado uma série de cursos e apresentações que objetivam esta formação. Obviamente o esforço ocorre em várias frentes, não apenas na elaboração do trabalho científico, porém este é o item fundamental de um programa deste tipo no qual a tese será defendida ao final.

É importante salientar que nem todos os alunos interessados neste tema são alunos de pós-graduação. Existem outros especialistas que tão somente desejam ter seus estudos publicados e reconhecidos por seus pares, outros ainda têm de desenvolver um trabalho científico para ascender a posições na sociedade da especialidade. Esta é a finalidade de se criar um suplemento que, acreditamos, será útil para diversos colegas e alunos da área da saúde. 